\title{
JARDINS DO OCIDENTE E DO ORIENTE: ORDENAMENTO OU RECRIAÇÃO DA PAISAGEM
}

\author{
WESTERN AND EASTERN GARDENS: LANDSCAPE PLANNING OR RECREATION
}

Cintia Maria Afonso*

\section{RESUMO}

Este trabalho analisa a estrutura formal de jardins ocidentais e orientais, buscando identificar similaridades, adaptações e variações ao longo do tempo. O intercâmbio cultural e de ideias entre os povos também diz respeito aos jardins, já que princípios de regularidade e simetria podem ser identificados em jardins do antigo Egito, Pérsia, Espanha, Índia, Itália e França. Já os antigos jardins chineses e japoneses seguem princípios baseados na compartimentação de espaços, assimetria e complementaridade de formas, retrabalhados nos jardins ingleses construídos a partir do século XVIII. A abordagem é direcionada à sequência ao longo do tempo mais do que à comparação de jardins de um mesmo período ou ao estudo de variações locais. Pretende-se que o conhecimento histórico possibilite a compreensão das transformações dos jardins, subsidiando atividades projetuais contemporâneas.

Palavras chave: Arquitetura paisagística (espaços). Espaços livres. Jardins históricos. História do paisagismo.

\section{ABSTRACT}

This paper analyses the formal structure of western and eastern gardens, studying its similarities as well as adaptations and variations over time. The interchanges of cultural elements and ideas among civilizations also relates to the gardens, seeing that principles of regularity and symmetry can be identified in the gardens of Egypt, Persia, Spain, India, Italy, and France. Ancient Chinese and Japanese gardens follow principles based on separate spaces, asymmetry and complementarity of forms, observed again in the English gardens designed after the 18th century. The approach is directed to the sequence over time, with no intent to compare gardens of the same period or to study local variations. Historic considerations are key to understanding the changes in the gardens, assisting contemporary design activities.

Keywords: Landscape Architecture (spaces). Open Spaces. Historic Gardens. Landscape History.

\footnotetext{
Universidade Paulista, Curso de Arquitetura e Urbanismo.

Rua Dr. Bacelar, 1.212, CEP 04026-002, Vila Clementino, São Paulo, SP.

CV: http://lattes.cnpq.br/5522634008332454

cintiafo@osite.com.br
} 


\section{INTRODUÇÃO}

Este texto apresenta os resultados do trabalho de pesquisa "A paisagem construída: jardins do Ocidente e do Oriente", desenvolvido como parte do Programa Individual de Pesquisa para Docentes da Universidade Paulista (UNIP).

A ideia de desenvolver este trabalho surgiu diretamente das atividades de docência na área de paisagismo do curso de arquitetura e urbanismo da universidade, e tem como objetivo fornecer elementos históricos que possam subsidiar a atividade projetual dos arquitetos paisagistas. Entende-se, aqui, que o conhecimento histórico é um dos requisitos para a compreensão do permanente processo de transformação das paisagens e é essa compreensão que permite aos profissionais desenvolver suas atividades de modo compatível com as condições e características de cada tempo e lugar.

Neste trabalho, jardim é entendido como um espaço intencionalmente criado por motivos práticos, sociais ou estéticos, onde são organizados elementos vegetais, água e pavimentos. Essa ideia vai ao encontro de duas definições encontradas na literatura. A primeira, apresentada por Aragão (2008, p. 27), conceitua jardim como:

O termo 'jardim' vem do francês (jardin) e designa todo terreno 'em geral com alamedas, onde se cultivam plantas ornamentais, úteis, ou para estudo'. Segundo essa acepção, o vocábulo está diretamente associado ao cultivo de plantas e, portanto, supõe o trabalho humano, o plantio e a disposição de espécies vegetais pelo homem. Estas podem ter uma finalidade ornamental (distribuídas ou não segundo parâmetros estéticos), útil (sendo empregadas no preparo de remédios caseiros, chás, doces e refeições) ou científica (sendo analisadas em sua composição, seu desenvolvimento e seus princípios ativos).

Uma outra conceituação é apresentada por Laurie (1983, p. 29), em que jardim é apresentado como:

El origen del significado de la palabra jardin se remonta al hebreo gan, proteger o defender, que sugiere, además, la presencia de uma valla o cerramiento, y oden o eden, que quiere decir placer o deleite. Por consiguiente, en el lenguaje actual, jardin es la combinación de dos vocablos que denotan un recinto de tierra para placer o deleite.

O processo intencional de criação de jardins envolve uma ação de projeto, claramente indicada por Macedo (1999, p. 13-14):

O conceito de arquitetura paisagística corresponde a uma ação de projeto específica, que passa por um processo de criação a partir de um programa dado, visando atender à solicitação de resolução de uma demanda social requerida por um interlocutor específico, seja ele o Estado, um incorporador ou uma família. Essa ação de projeto envolve uma preconcepção tridimensional, desenvolvida de modo a qualificar ambiental, estética e funcionalmente um espaço livre determinado, que 
pode, de acordo com a escala do projeto, ter um significado complementar ou estrutural em relação ao espaço.

Aragão (2008, p. 27-28) apresenta também uma informação que interessa especificamente a este trabalho, quando diz que nos jardins "[...] a combinação de materiais naturais e arquitetônicos deve-se a razões práticas, sociais, espirituais ou estéticas expressões da cultura que os criou. $\bigcirc$ jardim também pode ser entendido como uma expressão da relação entre a sociedade, o espaço e a natureza".

Nesse mesmo sentido, Santos (1994, p. 67) indica que "[...] em cada momento histórico, os modos de fazer são diferentes. $\bigcirc$ homem vai construindo novas maneiras de fazer coisas, novos modos de produção que reúnem sistemas de objetos e sistemas sociais". Assim, os jardins mudam ao longo do tempo, caracterizando-se como registros que expressam as culturas nas quais estão inseridos e comunicam seus valores e aspirações de forma visível.

Neste trabalho a opção analítica recaiu sobre o estudo dos princípios compositivos de jardins construídos desde os tempos da Antiguidade até o século XVIII. A seleção dos jardins foi organizada a partir da noção de que o intercâmbio cultural e de ideias existente entre os povos introduziu similaridades nos projetos desses espaços externos com adaptações e variações regionais. No processo de seleção dos estudos de caso, a ênfase recaiu mais sobre a sequência ao longo do tempo do que à comparação de jardins de um mesmo período ou às repetições e variações locais.

As informações sobre os princípios compositivos dos jardins estudados foram obtidas em textos que adotam essa mesma perspectiva sequencial (BOULTS; SULLIVAN, 2010; JELLICOE, G.; JELLICOE, S., 1995; PANZINI, 2013). As informações neles apresentadas foram complementadas por dados e análises integrantes de textos específicos relativos aos jardins chineses, japoneses, medievais, islâmicos, renascentistas, barrocos, persas e indianos, de modo a obter descrições e desenhos indicativos de sua estrutura formal.

O recorte temporal de análise também está fundamentado no intercâmbio cultural existente entre os povos. Os princípios formais dos jardins construídos pelas antigas civilizações da Mesopotâmia, Egito e Pérsia foram difundidos na Europa através das comunicações terrestres e marítimas estabelecidas entre essas regiões. Assim, o sistema de proporções e simetria baseado na geometria regular (princípio de organização dos jardins egípcios e persas) predominou nos jardins europeus anteriores ao século XVIII.

$\mathrm{Na}$ Ásia as primeiras civilizações se formaram na China e na Índia. Os antigos jardins hindus e budistas da Índia se perderam, restando os jardins construídos sob a influência islâmica. Já na China, existem relatos de parques construídos por volta de 230 a.C., período de formação da China Imperial. Nesses primeiros jardins, a valorização do mundo natural e dos aspectos sagrados a ele atribuídos estabeleceram o princípio norteador da concepção dos jardins chineses - a intenção de recriar a paisagem natural. A civilização japonesa foi fortemente influenciada pelos contatos com a China, e os princípios formais utilizados nos jardins chineses foram retrabalhados nos jardins japoneses. 
A intensificação dos contatos entre o Ocidente e o Oriente trouxe consigo um intercâmbio cultural mais intenso. As longas e perigosas viagens por terra ou mar se tornaram mais frequentes com os avanços nas técnicas de navegação verificados a partir do século XV. O consequente incremento das relações comerciais e a instalação de colônias europeias permanentes no Oriente propiciaram um estreito contato com a cultura e os hábitos dos povos asiáticos, relatados e divulgados na Europa pelos viajantes.

A intensificação dessas inter-relações culturais foi um dos fatores que propiciaram a transformação dos jardins europeus. Elementos chineses tornaram-se frequentes nos jardins da Europa continental e uma transformação conceitual mais profunda verificou-se nos jardins ingleses. Nestes, os princípios chinês e japonês de recriar as paisagens naturais adaptaram-se ao novo conceito de jardim surgido na Inglaterra do século XVIII - a intenção de criar uma paisagem inglesa ideal, obtida a partir dos elementos e características da paisagem natural.

É importante salientar que os conceitos de Ocidente e Oriente aqui adotados são tratados como denominações culturais para as regiões do mundo. Em seu sentido histórico, o Ocidente compreende a Europa, as Américas e a Austrália; o Oriente abrange a África Setentrional e a Ásia. Tal distinção vai além da simples diferença entre leste e oeste, pois é uma denominação que compreende as relações de poder e dominação estabelecidas. Tanto o mundo ocidental quanto o oriental abrangem múltiplas identidades culturais, sociais, políticas, econômicas, étnicas e religiosas, com suas respectivas localizações geográficas, que podem ser agrupadas de acordo com suas origens, afinidades e inter-relações.

\section{AS ORIGENS DA REGULARIDADE E DA SIMETRIA NOS JARDINS}

\subsection{A ESTRUTURA SIMÉTRICA DO JARDIM EGÍPCIO}

A partir da metade do segundo milênio a.C., as pinturas das tumbas passaram a incluir cenas de jardins que constituem o principal testemunho da forma compositiva e do tipo de plantas que formavam os jardins do Antigo Egito. Mais do que representações de jardins existentes, esses desenhos eram jardins simbólicos incluídos nos pertences das tumbas para deleite da alma ali enterrada.

As tumbas que contêm pinturas desse tipo pertenciam a ricos comerciantes ou administradores importantes que provavelmente possuíam em vida jardins comparáveis às pinturas. É provável, assim, que sua fonte de inspiração seja proveniente dos jardins que realmente existiam, fato documentado por escavações arqueológicas. Uma dessas pinturas murais, encontrada em Tebas, é conhecida como jardim de Sennefer.

O esquema mostra um jardim retangular cercado por um muro, com a área interna subdividida em espaços retangulares menores com utilizações diversas. $\bigcirc$ acesso ao jardim está localizado em uma abertura no renque externo de árvores e consiste em 
imponente portão. Chega-se à edificação principal por um caminho que passa sob uma pérgula central e, dos dois lados desse conjunto, existem canteiros e tanques de água. Margeando internamente o muro exterior, estão plantadas tamareiras, palmeiras e outras árvores de menor porte (JELLICOE, G.; JELLICOE, S.,1995, p. 112).
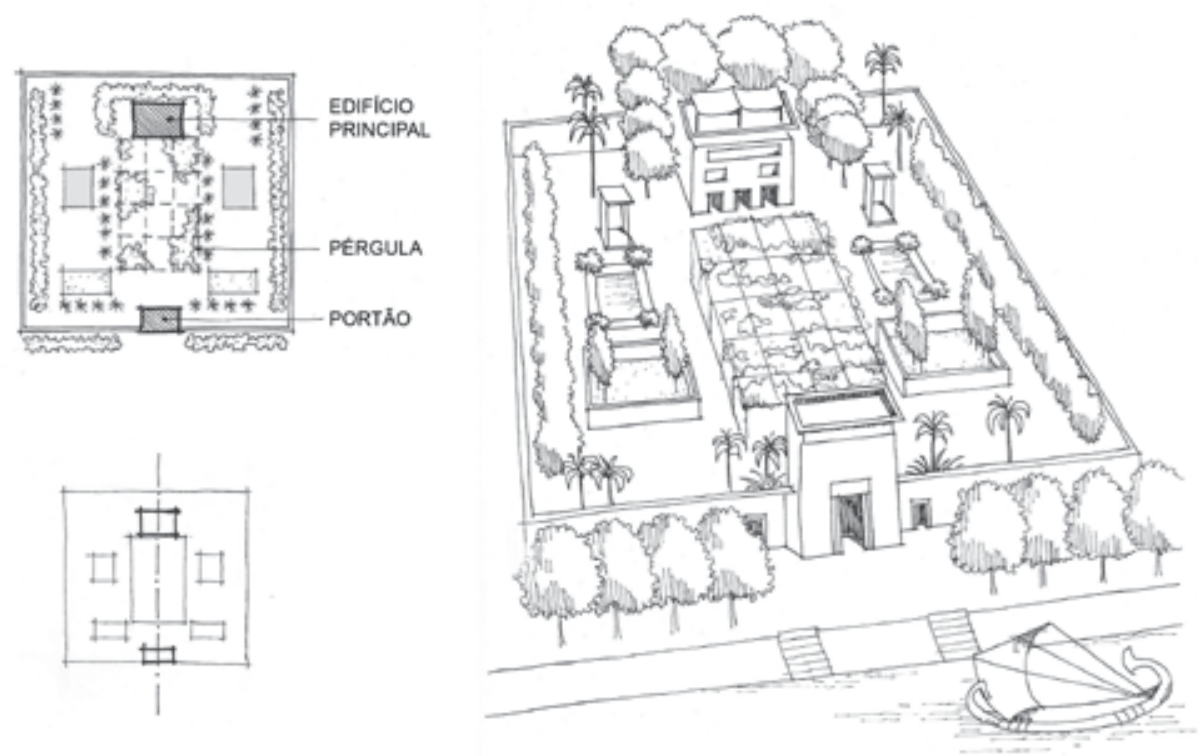

Figura 1 Representação do jardim de Sennefer em planta (acima, à esquerda) e perspectiva (à direita), acompanhada de esquema indicativo de seu eixo central de simetria (abaixo, à esquerda).

Autora: Cintia Maria Afonso, 2016.

Fontes: G. Jellicoe e S. Jellicoe (1995, p. 112) e Berrall (1978, p. 12).

Trata-se de um conjunto de formato retangular, organizado internamente a partir de um eixo central que parte do portão de acesso e termina na edificação principal. Os diversos subespaços do jardim estão organizados a partir desse eixo principal e são distribuídos em simetria perfeita, indicando a intenção de estabelecer um contraponto, baseado na geometria regular, às características da paisagem natural. Também o seu fechamento para o exterior, os tanques de água e as árvores são elementos indicativos da intenção de criar um refúgio, um local agradável em meio ao ambiente quente e desértico do Egito.

\subsection{A ESTRUTURA QUADRIPARTIDA DO JARDIM PERSA - PASÁRGADA}

Os jardins de Pasárgada, a primeira capital do Império Persa, também evidenciam as mesmas características de regularidade, mas apresentam uma importante inovação que criou um modelo de jardim reproduzido durante muitos séculos - a planta quadripartida.

Escavações arqueológicas realizadas no local da antiga cidade revelaram a existência de um palácio real com jardins construídos para ser refúgios em meio ao ambiente 
quente e desértico da região. Sua base é um engenhoso sistema de irrigação no qual a água é captada em poços ou pequenos córregos existentes nas proximidades e conduzida até o jardim através de canais. Os trabalhos permitiram descobrir um sistema de canais construídos em pedra, que dividiam a área em dois retângulos. Esse sistema refrescava o ambiente e permitiu o plantio de flores e árvores que sombreavam o jardim. Nos cantos deste existiam um segundo palácio e dois pavilhões menores. $\bigcirc$ pórtico do palácio principal abria diretamente para o jardim, e um trono em pedra, fixado em seu centro, oferecia ao rei visão privilegiada e abrangente do conjunto (STRONACH, 1978, p. 107-112). A figura 2 reconstrói esse espaço e mostra a estrutura do jardim principal que dava acesso ao palácio.

O desenho demonstra tratar-se de um conjunto de implantação formal, certamente construído para expressar a grandeza do Império Persa. As motivações que conduziram à adoção desse desenho apresentam significado simbólico importante, como apresenta Panzini (2013, p. 128-130):

A forma em cruz e sua eventual multiplicação em grelhas ortogonais representava um método racional de divisão do jardim, tendo em vista que constituía uma eficaz solução para a irrigação. Geralmente, a água provinha de um único ponto de alimentação e sua racional distribuição pela rede de canais permitia atingir toda a vegetação. [...] No entanto, o êxito da planta quadripartida está geralmente associado a motivações simbólicas e funcionais, mas também explicitamente políticas; esse tipo de solução com arranjo axial era tanto funcional quanto adequado para exaltar a dignidade real e, por isso, foi amplamente usado nos grandes jardins das cortes islâmicas, arrematando a hierarquia visual dos percursos que celebravam o soberano enquanto pessoa e instituição.

Esse jardim é considerado o exemplar mais antigo dos chahar bagh, cujo princípio se tornou a característica dominante dos jardins persas nos séculos seguintes. No chahar bagh, que em persa significa 'quatro lotes' ou 'quatro jardins', o jardim tem formato quadrado ou retangular e é subdividido em quatro segmentos por dois canais que se cruzam no centro do complexo (PANZINI, 2013, p. 128). Muitos desses jardins têm pavilhões cobertos que formam um conjunto unificado com as áreas externas, permitindo aos usuários apreciar plenamente a vista do jardim enquanto permanecem em ambiente interno. No entanto, é importante salientar que a divisão em quatro partes não é diretamente verificada nas escavações arqueológicas, já que a área está dividida pelos canais em dois retângulos, e não quatro. A divisão em quatro partes é uma interpretação posterior das intenções de projeto.

Quando os árabes conquistaram a Pérsia, encontraram os grandes complexos palacianos e seus jardins, e foi a partir de suas características que os princípios de organização espacial dos jardins islâmicos foram definidos. Variações da planta quadripartida foram adotadas pelas cortes islâmicas e difundidas por todo o Império Árabe, que ocupou regiões da Ásia, norte da África e sul da Europa. 
Jardins do Ocidente e do Oriente: Ordenamento ou Recriação da Paisagem
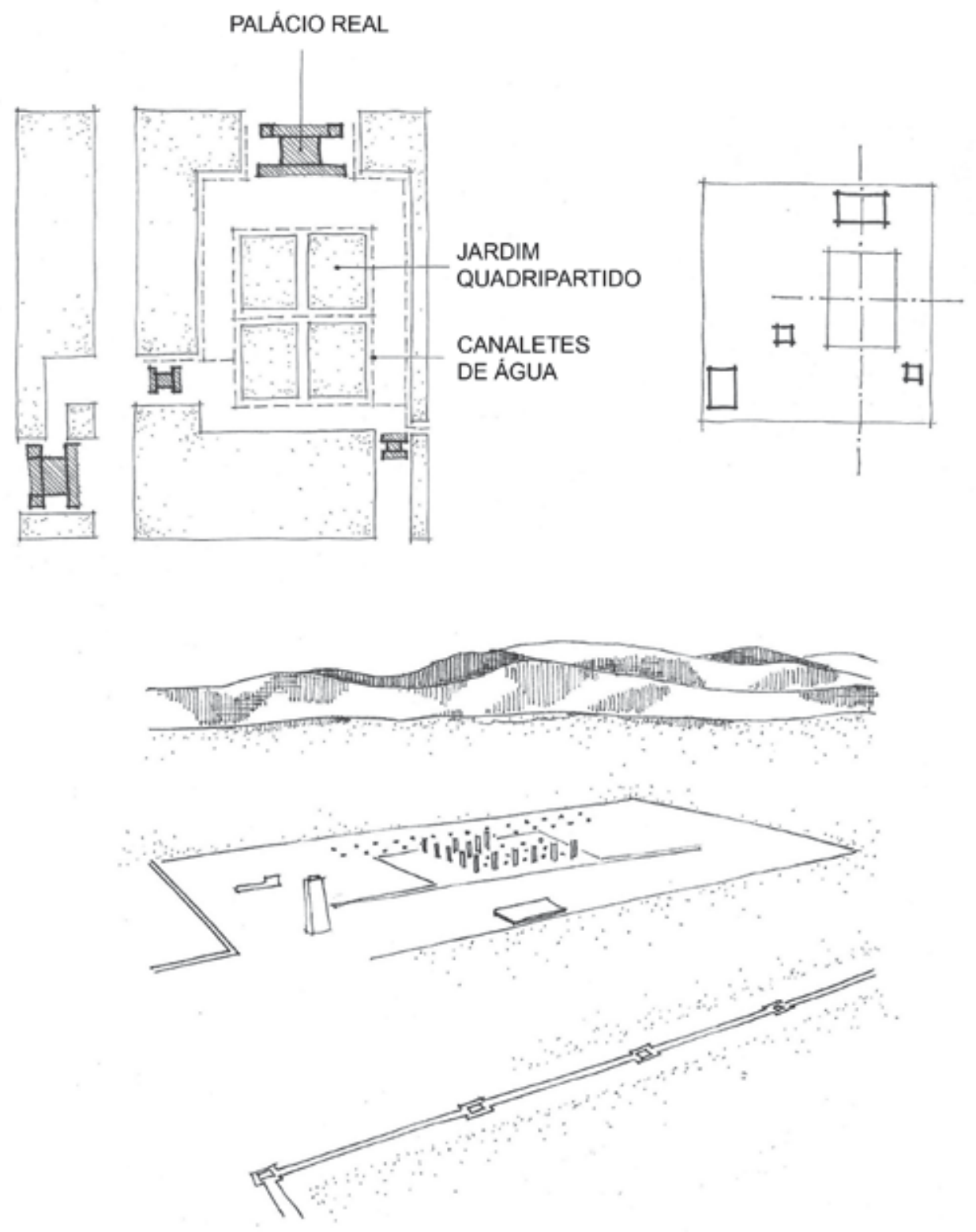

Figura 2 Desenho elaborado a partir de evidências arqueológicas, mostrando a estrutura do mais antigo exemplar de jardim quadripartido (acima, à esquerda). O palácio imperial de Pasárgada está localizado na porção superior do desenho e o jardim quadripartido está posicionado à frente do palácio, no centro do conjunto. Outros edifícios menores também estão distribuídos em torno do jardim central. O esquema indicativo da organização formal do conjunto (acima, à direita) apresenta os dois eixos entrecruzados que estruturam o jardim central e definem a relação entre o jardim e o palácio imperial. A perspectiva (abaixo) mostra as ruínas do palácio e os remanescentes do canalete de água utilizado para irrigação.

Autora: Cintia Maria Afonso, 2016.

Fonte: Kidd (2013, p. 3). 


\section{JARDINS EUROPEUS E MOGÓIS'1 : A PAISAGEM CONSTRUIIDA COMO ORDENAMENTO E TRANSFORMAÇÃO DA PAISAGEM NATURAL}

Os jardins europeus anteriores ao século XVIII, discutidos a seguir, apresentam estrutura formal similar, adotando princípios compositivos baseados na geometria regular, nos eixos de simetria e no emprego de um sistema de dimensões e proporções indicativo da intenção de dispor uma matriz racional ideal sobre a paisagem natural.

Essa intenção já estava presente nos jardins do Antigo Egito e da Pérsia. Autores como G. Jellicoe e S. Jellicoe, (1995, p. 23) e Panzini (2013, p. 60) atribuem essa idealização, inicialmente, à contemplação do efeito miraculoso da irrigação sobre a paisagem desértica dessas regiões e, em um segundo momento, à sua comparação com o Paraíso. Em sua pureza e perfeição, o Paraíso só poderia ser um lugar ideal, representado por essas sociedades antigas como um lugar protegido do mundo exterior hostil, com água, sombra e todas as frutas da Terra. Consequentemente, sua expressão também deveria estar baseada em formas puras.

Posteriormente, com o desenvolvimento da filosofia e as explicações ocidentais para o universo, a vida e o homem passaram a ser fundamentados em bases racionais e o saber empírico (fundamentado em experiências casuais e com objetivos práticos e imediatos) passou a ser sistematizado à luz da razão. $\bigcirc$ entendimento de que o homem racional é superior à natureza selvagem foi novamente compatível com a ideia de utilizar a ordem geométrica regular nos jardins, agora com a intenção de organizar seus elementos compositivos à luz da razão.

\subsection{UM JARDIM PERSA NA EUROPA - ALHAMBRA}

A ideia islâmica de jardim, originada no Oriente Médio, chegou ao norte da África e à Espanha através dos árabes. A construção da fortaleza de Alhambra iniciou-se em 1248, quando os árabes ocuparam a Península Ibérica (COLE, 2014, p. 176). Dentro de suas muralhas existem dois palácios, que foram construídos durante o século XIV. Lá estão os mais bem preservados jardins islâmicos europeus. Consistem em duas grandes unidades, cada uma formada por um conjunto de pavilhões internos implantados em torno de um pátio central retangular.

O primeiro desses pátios é o Pátio da Alberca, ou dos Arrayanes, que tem formato retangular e um grande espelho d'água central com duas fileiras lineares de arbustos plantadas ao longo das duas laterais maiores do pátio. O Pátio dos Leões também é uma estrutura de planta retangular, aqui quadripartida, rodeada por uma galeria

\footnotetext{
A designação Mogol foi obtida em Cole (2014, p. 180), mas Parker (1995, p. 168) apresenta a denominação Mughal. Em língua inglesa, Boults e Sullivan (2010, p. 119) indicam Mughal Empire, e Jellicoe (1995, p. 48), Mughul India. Trata-se de um império que dominou a Índia entre 1526 e 1857. Seu processo de formação teve início durante o século XIV, quando Timur ocupou a região da antiga Pérsia a partir da Ásia Central (BOULTS; SULLIVAN, 2010, p. 119). Babur, descendente de Timur, conquistou Delhi em 1526 e ali formou o Império Mogol (ou Mughal), que teve seus domínios expandidos no final do século XVI, quando seu neto, Akbar, ocupou a região da Caxemira. O império foi extinto em 1857 pelos invasores britânicos.
} 
Jardins do Ocidente e do Oriente: Ordenamento ou Recriação da Paisagem

com colunas de mármore para a qual se abrem vários compartimentos internos provavelmente usados pelo monarca como ambientes de uso privativo (HOAG, 1963, p. 27). $\bigcirc$ espaço é subdividido por quatro caminhos em cruz com canaletes centrais de mármore branco, que conduzem a água proveniente de pequenos tanques circulares situados nas extremidades do pátio para uma fonte localizada no centro do conjunto, sustentada por doze leões.

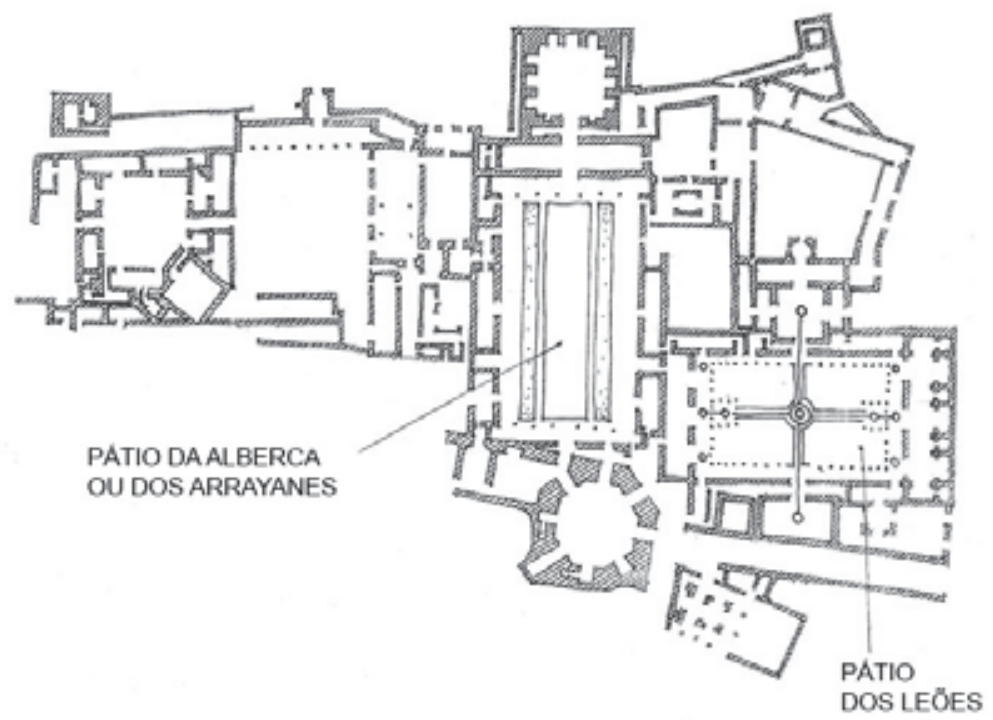

Figura 3 Planta do conjunto de palácios de Alhambra na qual se destacam o Pátio da Alberca e o Pátio dos Leões. Autora: Cintia Maria Afonso, 2016.

Fonte: Hoag (1963, figura 65).
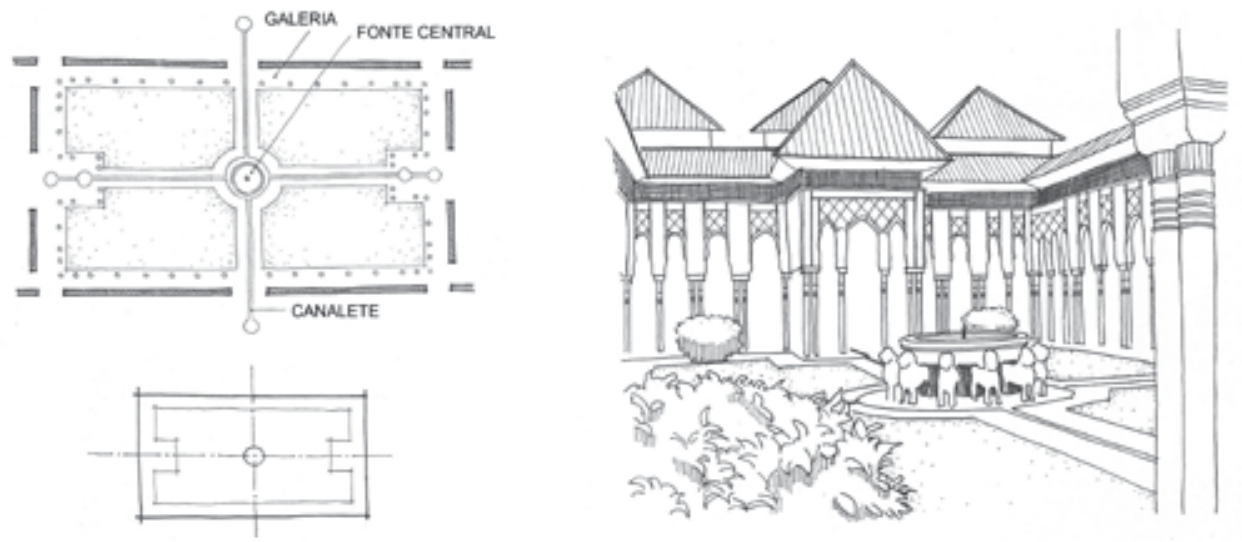

Figura 4 Representação do Pátio dos Leões em planta (acima, à esquerda) e perspectiva (à direita), acompanhada de esquema indicativo de sua estrutura quadripartida (abaixo, à esquerda).

Autora: Cintia Maria Afonso, 2016.

Fontes: Boults; Sullivan (2010, p. 32-33); G. Jellicoe e S. Jellicoe (1995, p. 59-60). 


\subsection{UM JARDIM PERSA NA ÍNDIA - TAJ MAHAL}

Não foi somente na Europa e África que os árabes construíram seus famosos jardins. Os imperadores mogóis, procedentes da Ásia Central, ocuparam a região da antiga Pérsia e posteriormente a Índia, onde formaram o Império Mogol. No início do processo de expansão territorial, os conquistadores adotaram várias tradições culturais persas, inclusive os jardins tipo chahar bagh, posteriormente construídos na Índia.

A paisagem da Caxemira, com seus vales verdes, lagos e altos cumes, tornou-se um dos lugares preferidos para a implantação dos famosos jardins imperiais mogóis. Ali também foram construídos os jardins mausoléus, que combinaram aspectos do jardim islâmico com a tradição da Ásia Central de construção de cemitérios jardim (BOULTS; SULLIVAN, 2010, p. 119). Neles o túmulo é localizado em posição central e o jardim é construído ao seu redor, configurando um espaço privilegiado para observação do monumento principal, o mausoléu.

O mais célebre jardim mausoléu é o Taj Mahal, construído entre 1632 e 1648 pelo imperador mogol Shah Jahan para sua esposa favorita, a quem chamava de Mumtaz Mahal, falecida após dar à luz ao $14^{\circ}$ filho (BOULTS; SULLIVAN, 2010, p. 123). 0 conjunto é composto pelo mausoléu, edifícios secundários e um imenso jardim tipo chahar bagh, que apresenta algumas variações significativas à sua composição típica. A mais importante é a localização do edifício principal, aqui posicionado na extremidade norte do jardim em vez de situado na interseção dos canais de água. Essa interseção, o centro do chahar bagh, é marcada por um tanque de água elevado, do qual partem quatro canais de água que subdividem o jardim em quatro setores. $\bigcirc$ edifício principal está implantado sobre uma plataforma elevada com quatro minaretes marcando os cantos desse terraço. Nos dois lados da plataforma, já no nível do jardim, foram construídos dois edifícios de apoio ao mausoléu, espaço destinado a orações e um local para descanso e encontro.

A figura 5 permite visualizar o esquema de composição do conjunto, indicando sua subdivisão em três setores. $\bigcirc$ primeiro, situado na porção inferior do esquema, abriga um conjunto de edifícios posicionados nas bordas de um espaço aberto central. A partir de um edifício monumental de acesso, chega-se ao setor central, o jardim tipo chahar bagh, com sua estrutura quadripartida. O terceiro setor, situado na porção superior do esquema, mostra o edifício principal - o mausoléu -, implantado em posição central, ladeado pelos dois pavilhões de apoio.

Todo o conjunto está organizado em função do mausoléu, ponto focal da composição. A mesma forma quadripartida usada para a exaltação do poder dos governantes foi aqui utilizada para enfatizar a importância do edifício principal, o belo e imponente edifício revestido em mármore branco. 
Jardins do Ocidente e do Oriente: Ordenamento ou Recriação da Paisagem
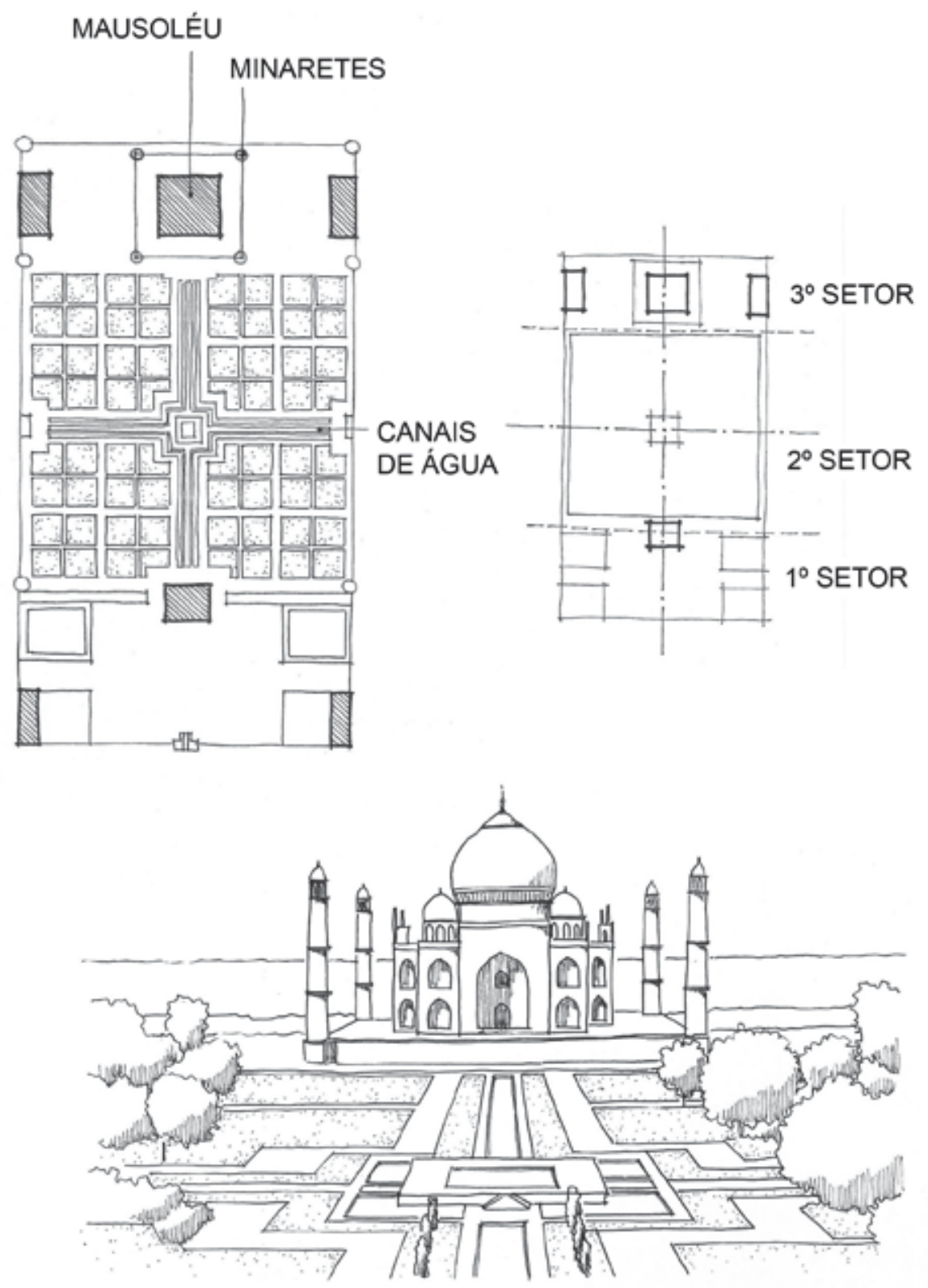

Figura 5 Representação do Taj Mahal em planta (acima, à esquerda) e perspectiva (abaixo). Acima, à direita, apresenta-se esquema indicativo dos três setores do conjunto, com o eixo longitudinal de simetria e o jardim quadripartido construído no setor central.

Autora: Cintia Maria Afonso, 2016.

Fonte: G. Jellicoe e S. Jellicoe, S (1995, p. 54). 


\subsection{A PLANTA QUADRIPARTIDA NOS CLAUSTROS MEDIEVAIS ABADIA DE FONTENAY}

A estrutura quadripartida não foi adotada somente nos jardins islâmicos. $\bigcirc$ mesmo princípio está presente também nos claustros dos mosteiros medievais, que começaram a ser construídos na Europa por volta do século V, a partir da criação da Ordem de São Bento, que estabeleceu a vida monástica fundamentada no trabalho e na oração.

As configurações espaciais dos edifícios monásticos medievais apresentam grande similaridade, com a igreja e o claustro anexo ocupando posição central na sua estrutura. $O$ claustro (pátio quadrado ou retangular rodeado por uma galeria aberta) é sempre um espaço privilegiado, dedicado às atividades espirituais e intelectuais dos monges - ao mesmo tempo lugar de oração, meditação, repouso e encontro, além de constituir-se também como passagem entre os diversos ambientes internos cotidianamente usados.

A Abadia de Fontenay, construída entre 1139 e 1147 e localizada na região da Borgonha (BARRAL I ALTET, 2001, p. 138), exemplifica esses princípios. Trata-se de um conjunto que apresenta características unificadas e quase integralmente datado do século XII, quando foram construídas a igreja, o claustro, a sala - também ocupada pelo scriptorium da abadia -, os dormitórios dos monges e a forja. $\bigcirc$ claustro está localizado ao lado da igreja, como na maioria dos conjuntos monásticos medievais.

A construção do claustro foi finalizada em 1147 (BARRAL I ALTET, 2001, p. 139) e segue princípios de simplicidade e austeridade compatíveis com as atividades que lá se desenrolavam - meditação, oração e trabalho manual. De forma quadrangular, é contornado por quatro galerias que se abrem para o pátio central por meio de aberturas de volta perfeita, fazendo a conexão entre o pátio descoberto e os ambientes fechados distribuídos ao seu redor. $\bigcirc$ jardim atualmente é bastante simples, mas provavelmente também seguia os princípios adotados na maioria dos mosteiros - canteiros delimitados por quatro caminhos em cruz, algumas árvores e uma fonte ou poço central (PANZINI, 2013, p. 181).

Autores como Panzini (2013, p. 181-182) consideram o claustro uma derivação direta do peristilo existente nas habitações romanas, já que apresenta as mesmas características de espaço protegido e isolado do exterior, o que provavelmente decorre do contato com as antigas cidades romanas. Diferentemente, G. Jellicoe e S. Jellicoe (1995, p. 139) relacionam a origem do claustro ao contato com os jardins islâmicos espanhóis e, consequentemente, com os jardins quadripartidos da Pérsia. De qualquer modo, as relações sugeridas são indicativas de um processo de reconversão das configurações arquitetônicas mais antigas, e os claustros se caracterizam não como novidade, mas como renovação de antigos espaços. 
Jardins do Ocidente e do Oriente: Ordenamento ou Recriação da Paisagem
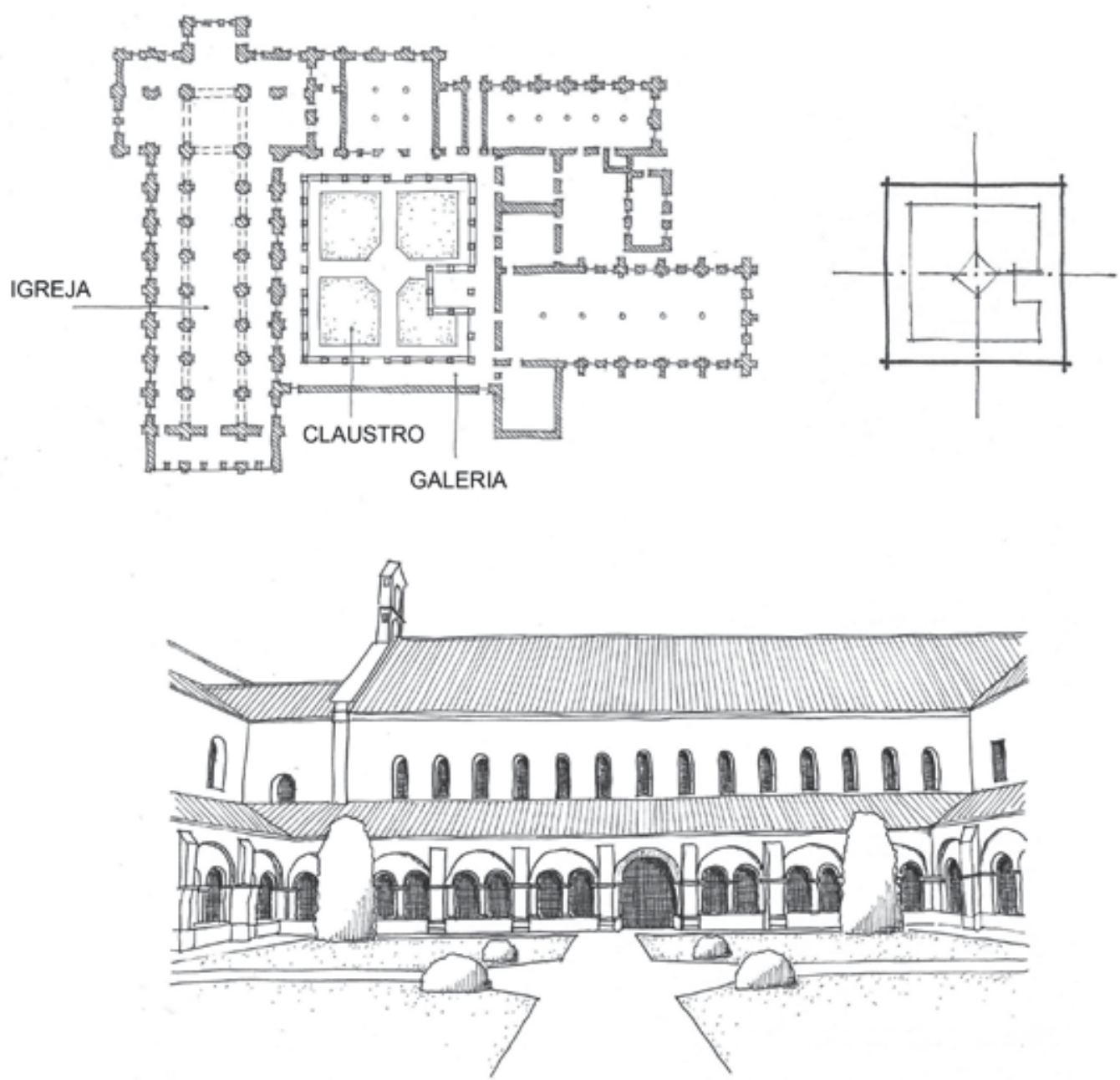

Figura 6 Planta dos edifícios centrais da Abadia de Fontenay (acima, à esquerda), com a igreja à esquerda e o claustro ao seu lado, ocupando posição central em relação aos demais edifícios. O claustro também tem estrutura quadripartida, como indicam o esquema (acima, à direita) e a perspectiva (abaixo) que representa suas características atuais.

Autora: Cintia Maria Afonso, 2016

Fonte: Barral I Altet (2001, p. 138). 


\subsection{A SIMETRIA PERFEITA NOS JARDINS ITALIANOS VILLA LANTE}

As villas italianas foram projetadas a partir da concepção humanista do Renascimento e se transformaram em modelos que se difundiram por toda a Europa, com seus jardins terraceados, integração à paisagem circundante, trabalho com a água e poda topiária em desenhos orgânicos.

Com o fortalecimento das prósperas famílias burguesas italianas, que buscavam reconhecimento, distinção e poder, as ricas residências construídas a partir dos séculos XIV e XV abandonaram o modelo medieval de jardim fechado para o exterior e, apesar de muradas ou cercadas, abriram-se para a paisagem circundante. Muitas dessas propriedades foram implantadas a meia encosta e em locais com belas visuais, intencionalmente consideradas e aproveitadas no projeto. A inclinação dos terrenos também induziu a formação de platôs, implantados em níveis variados e encaixados harmoniosamente no terreno original. Surgiram, assim, os famosos jardins terraceados.

Outro aspecto introduzido nas villas renascentistas foi o planejamento de sequências de espaços dispostos ao longo de um eixo organizador. Nesse tipo de projeto, cada espaço tem uma configuração específica e se constitui em uma unidade espacial distinta, possibilitando experiências espaciais contrastantes. No entanto, sua organização ao longo de um eixo traz como resultado uma ordem geral que subordina as várias partes à força compositiva do conjunto. Sequências desse tipo foram criadas em vários projetos de jardins e se tornaram bastante difundidas a partir da segunda metade do século XVI. O edifício principal era frequentemente posicionado no alto de uma colina e acessado a partir de uma sequência de terraços ajardinados construídos na encosta. Isso resultava na orientação do observador para um único ponto focal dominante, em vez de configurar uma profusão de unidades espaciais separadas.

O projeto da Villa Lante foi desenvolvido a partir dos princípios aqui apresentados. A villa foi construída em Bagnaia (localidade situada nos arredores de Viterbo, na Itália), para o cardeal Gianfrancesco Gambara, e projetada por Giacomo Barozzi da Vignola, assessorado por Tommaso Ghinucci - especialista em obras hidráulicas, foi responsável pelo trabalho com as águas (BOULTS; SULLIVAN, 2010, p. 82).

O conjunto foi implantado em terraços sequenciais ascendentes, organizados linearmente a partir de um eixo central intencionalmente marcado e enfatizado pelo uso da água. Os jardins foram distribuídos em quatro terraços, interligados por dois planos inclinados e organizados a partir de um eixo central que atravessa longitudinalmente o conjunto e estabelece a simetria do desenho, definindo inclusive o posicionamento dos dois edifícios principais.

O resultado é notável. Apesar de formado por ambientes de caráter e desenhos bastante distintos, apresenta marcante coesão, proporcionada pela força do eixo central e pela perfeita simetria presente em todos os espaços. 
Jardins do Ocidente e do Oriente: Ordenamento ou Recriação da Paisagem
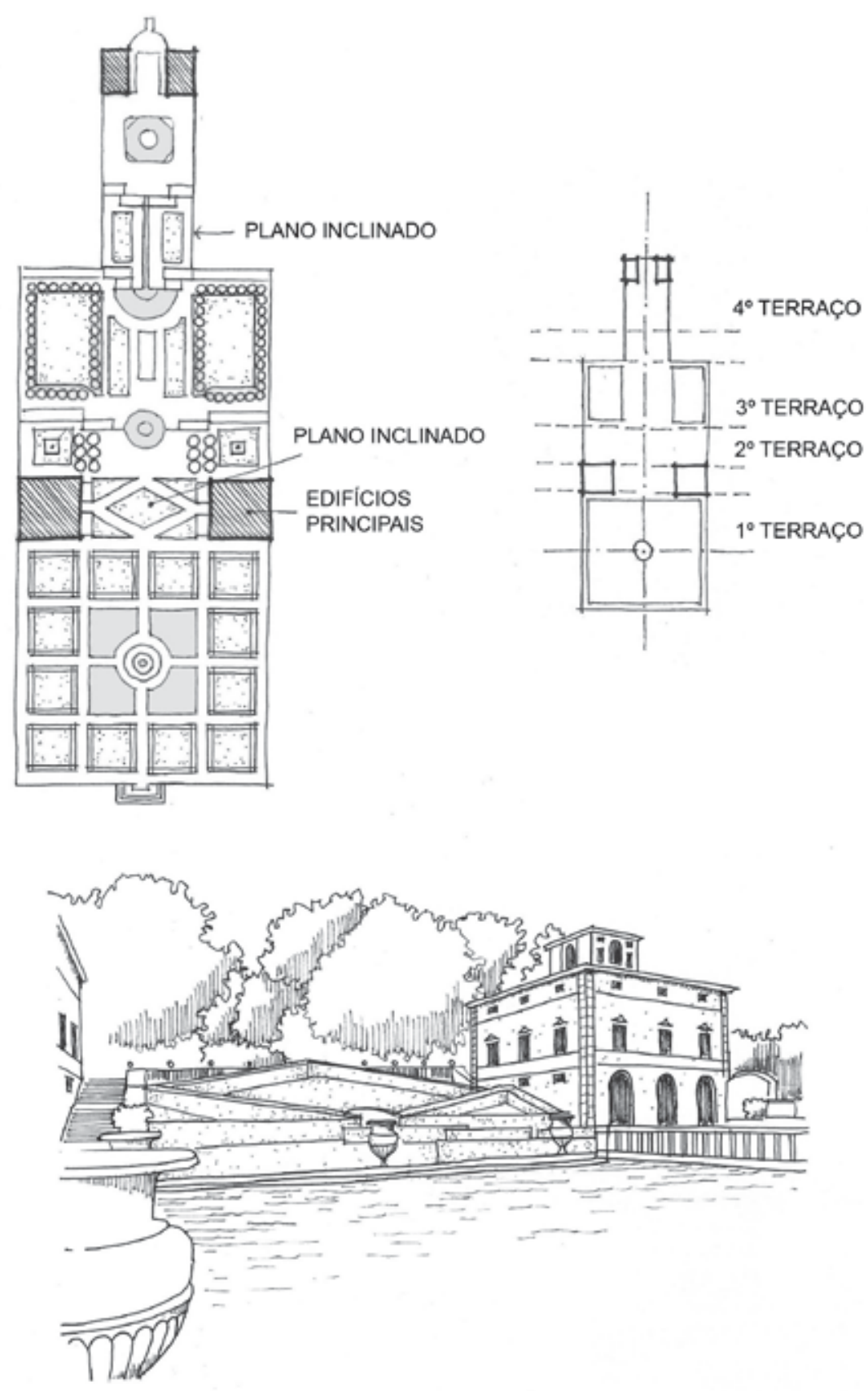

Figura 7 Representação da Villa Lante em planta (acima, à esquerda) mostrando a implantação do conjunto de edifícios e jardins, e em perspectiva (abaixo), destacando as características do plano inclinado que faz a interligação entre o primeiro e o segundo terraços. Acima, à direita, esquema indicativo da estrutura formal do conjunto, com o eixo longitudinal de simetria, os quatro terraços e o jardim quadripartido construído no primeiro terraço.

Autora: Cintia Maria Afonso, 2016.

Fonte: G. Jellicoe e S. Jellicoe (1995, p. 160-162). 


\subsection{O EIXO MONUMENTAL NO JARDIM FRANCÊS VAUX-LE-VICOMTE}

Até o século XVI, as características medievais ainda estavam presentes nos castelos da França, que tinham muros altos e espaços compartimentados, mas durante o século XVII e sob a influência dos jardins das villas italianas, os jardins franceses começaram a ser concebidos a partir de um desenho integrado.

O grande mestre do paisagismo barroco francês, Andrè le Nôtre, aboliu definitivamente a ideia de compartimentação dos espaços e a substituiu por uma organização que privilegiava o conjunto em sua totalidade. Sua primeira grande obra foi Vaux-le-Vicomte, propriedade rural construída para o Ministro de Estado Nicolas Fouquet, com uma enorme mansão emoldurada por um grandioso jardim.

O princípio de trabalho adotado por Le Nôtre pode ser entendido como uma evolução dos modelos italianos, com o uso de eixos direcionais (geralmente dois eixos perpendiculares) que direcionam o olhar, ampliam a sensação de distância e ordenam a disposição dos espaços ajardinados e dos bosques circundantes. No entanto, o uso de dois eixos perpendiculares confere certo dinamismo à composição, rompendo com o princípio renascentista baseado na ordenação por simetria perfeita. Uma importante diferença é também a utilização dos bosques circundantes como elemento central de composição do jardim, delimitando e enquadrando o conjunto.
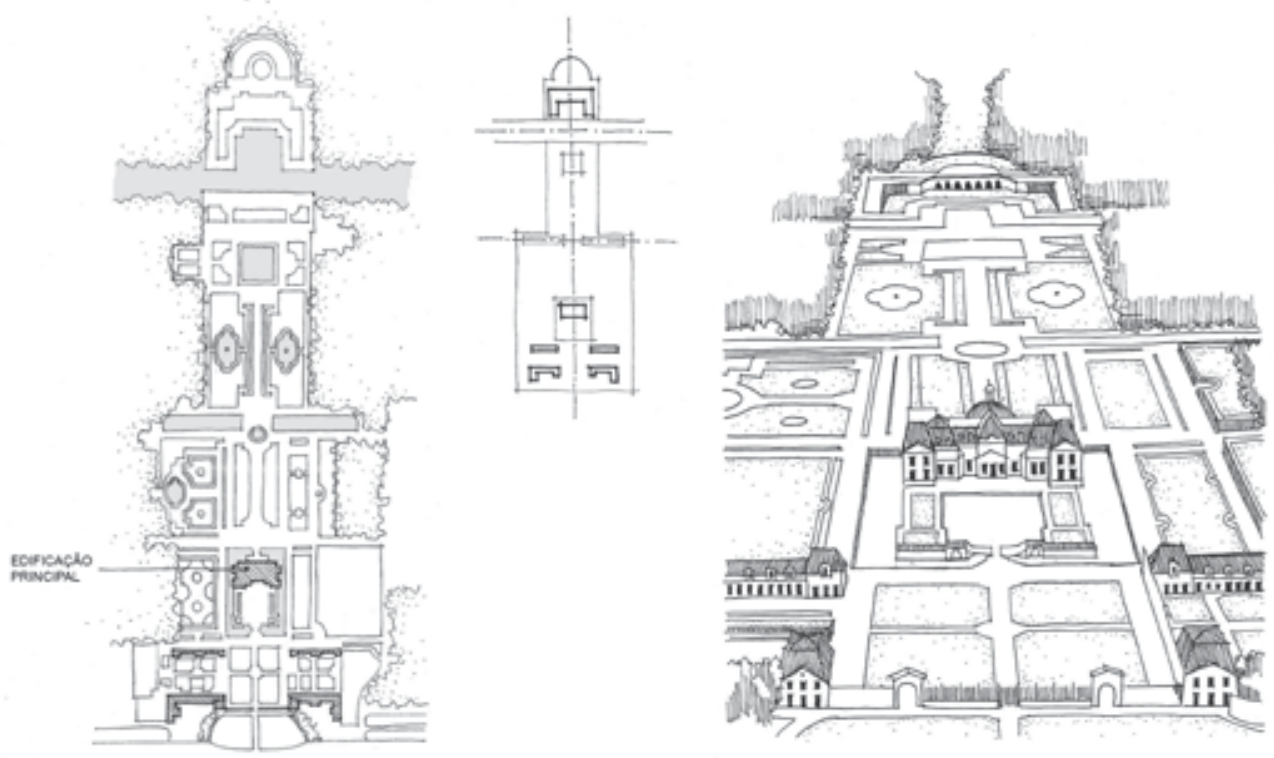

Figura 8 Representação dos jardins de Vaux-le-Vicomte em planta (à esquerda) e perspectiva (à direita). O esquema central indica o grande eixo longitudinal e os eixos transversais estruturadores do conjunto. Autora: Cintia Maria Afonso, 2016.

Fontes: Boults e Sullivan (2010, p. 138); G. Jellicoe e S. Jellicoe (1995, p. 182). 
O resultado é um conjunto unificado e coerente, de escala grandiosa, que se apresenta como espaço de ostentação e cerimônia. Esses efeitos de grandiosidade e ostentação são obtidos pelo uso dos citados eixos direcionais que organizam o espaço - um eixo longitudinal principal, cortado por eixos transversais - e pelo contraste entre o eixo principal e o pano de fundo formado pelos bosques existentes ao redor. Tais estratégias de projeto direcionam a visão para o horizonte, o que permite a visualização do jardim em sua totalidade a partir de um único ponto de vista.

A aproximação do observador revela novas complexidades, já que o espaço é subdividido em diferentes níveis, enriquecidos por espelhos e canais de água e por desenhos obtidos com poda topiária da vegetação. Mas esse enriquecimento não minimiza a importância da edificação principal, pois o terraceamento, os parterres (canteiros decorados com plantas floríferas, formando desenhos em volutas e ramagens) e os espelhos d'água estabelecem relação axial com o castelo, implantado em posição central para enfatizar e destacar sua importância.

Neste projeto Le Nôtre apresentou todos os elementos que posteriormente utilizaria com grande sucesso: avenidas radiais cortadas nos bosques ou ladeadas por árvores, fontes combinadas com grandes planos de água, os trabalhados e abertos parterres - em contraste com os densos bosques - e a multiplicidade de níveis obtidos por cerceamento do terreno.

\section{JARDINS CHINESES E JAPONESES - A PAISAGEM CONSTRUÍDA COMO RECRIAÇÃO DA PAISAGEM NATURAL}

Os jardins chineses e japoneses tiveram sua estrutura fundamentada em três princípios distintos, estabelecidos na China Antiga: 1) princípio das formas complementares: a harmonia surge a partir da complementariedade entre feminino e masculino, áspero e suave, montanha e planície, rocha e água; 2) princípio da sucessão contínua de visuais: os ambientes são criados de modo que se passe de uma vista para outra, oferecendo um prazer diferente em cada situação, como pavilhões com vista para o pôr do sol, bancos em locais onde a lua está refletida na água; 3) princípio da assimetria: posicionamento dos edifícios, conjuntos de árvores, pedras e pontes segue os movimentos da natureza, buscando recriar sua harmonia.

Esses princípios derivam da filosofia e da arte. O céu, montanhas e mares, rios e rochas são entendidos pelo taoismo como materializações de espíritos irmãos do homem. Isso levou à valorização do mundo natural e à busca de contato mais próximo com a natureza, seja através de pinturas que representassem a paisagem natural, seja através de reproduções tridimensionais, como os jardins (JELLICOE, G.; JELLICOE, S., 1995, p. 68). Partindo desse princípio, o jardim chinês foi estruturado por rochas e água: as rochas simbolizando as montanhas e representando a força masculina (yin) e a água simbolizando a força feminina (yang) [(BOULTS; SULLIVAN, 2010, p. 39)]. 
Os jardins chineses também foram associados à pintura de paisagens, que era feita em rolos de formato horizontal, com várias pinturas sequenciais que deveriam ser apreciadas progressivamente (PANZINI, 2013, p. 368-369). Seguindo o procedimento de pintura em rolo, o jardim chinês assumiu outra importante característica - a composição por cenas, com a construção de uma sequência de ambientes e vistas descoberta a partir de percursos sinuosos que dissimulavam a extensão do jardim e a interligação das partes (PANZINI, 2013, p. 371). Assim, os jardins eram projetados para serem lentamente descobertos a partir de um percurso preestabelecido.

As origens do jardim japonês são similares às do jardim chinês, ligadas à paisagem e aos aspectos sagrados a ela atribuídos. As crenças xintoístas ancestrais (o xintoísmo pregava a veneração da natureza) e a rica paisagem natural do Japão fizeram com que, desde o início, a natureza não fosse percebida como realidade hostil. Sucessivas ondas culturais chegaram ao Japão a partir da Ásia, misturando ideias continentais aos costumes locais. Esse conjunto de influências levou os japoneses a considerar a natureza não como realidade a ser dominada, mas como fonte sagrada de vitalidade da qual o homem se aproxima com admiração e espírito humilde em busca de contato harmonioso com o mundo natural (LODARI, 2005, p. 164). Partindo desse princípio, os jardins japoneses são construídos para ressaltar a beleza das paisagens, mesmo que isso não signifique manter seus elementos nas formas originais. A beleza natural é recriada através da disposição intencional de árvores, arbustos e pedras, estabelecendo ritmos e padrões que simbolizam e enfatizam aspectos e características da paisagem natural.

\subsection{SETORIZAÇÃO E ASSIMETRIA NO JARDIM CHINÊS YUYUAN}

O jardim Yuyuan foi construído na cidade de Shangai entre 1559 e 1577 por um oficial do governo chamado Pan Yunduan. Apesar de modificado algumas vezes pelos sucessivos proprietários, é um dos raros jardins tradicionais chineses que ainda permanece preservado, graças à restauração iniciada em 1956 pelo governo de Shangai.

Nele foram aplicados os três princípios típicos da tradição chinesa de construção de jardins: 1) a subdivisão do jardim em várias cenas - distintas, mas sequenciais; 2) o uso das rochas e da água como elementos de conexão simbólica com a paisagem natural da China; 3) o uso da assimetria como estratégia para obter harmonia.

De nenhum ponto do jardim é possível apreender o conjunto em toda a extensão, já que o espaço é propositalmente fracionado por meio de elevações, muros e anteparos. $\bigcirc$ acesso aos vários setores é feito através de corredores, passagens e portais integrados ao jardim. Nesse processo de subdivisão, a legibilidade do conjunto é descartada em favor das composições múltiplas, vivenciadas como ricas sequências espaciais nas quais se combinam espaços mais estreitos e espaços mais amplos. Assim, o jardim não proporciona a experiência da grandiosidade única: é necessário escolher o ritmo certo e fazer paradas frequentes para que, observando os detalhes e os pontos de conexão, seja possível compreender o conjunto. 

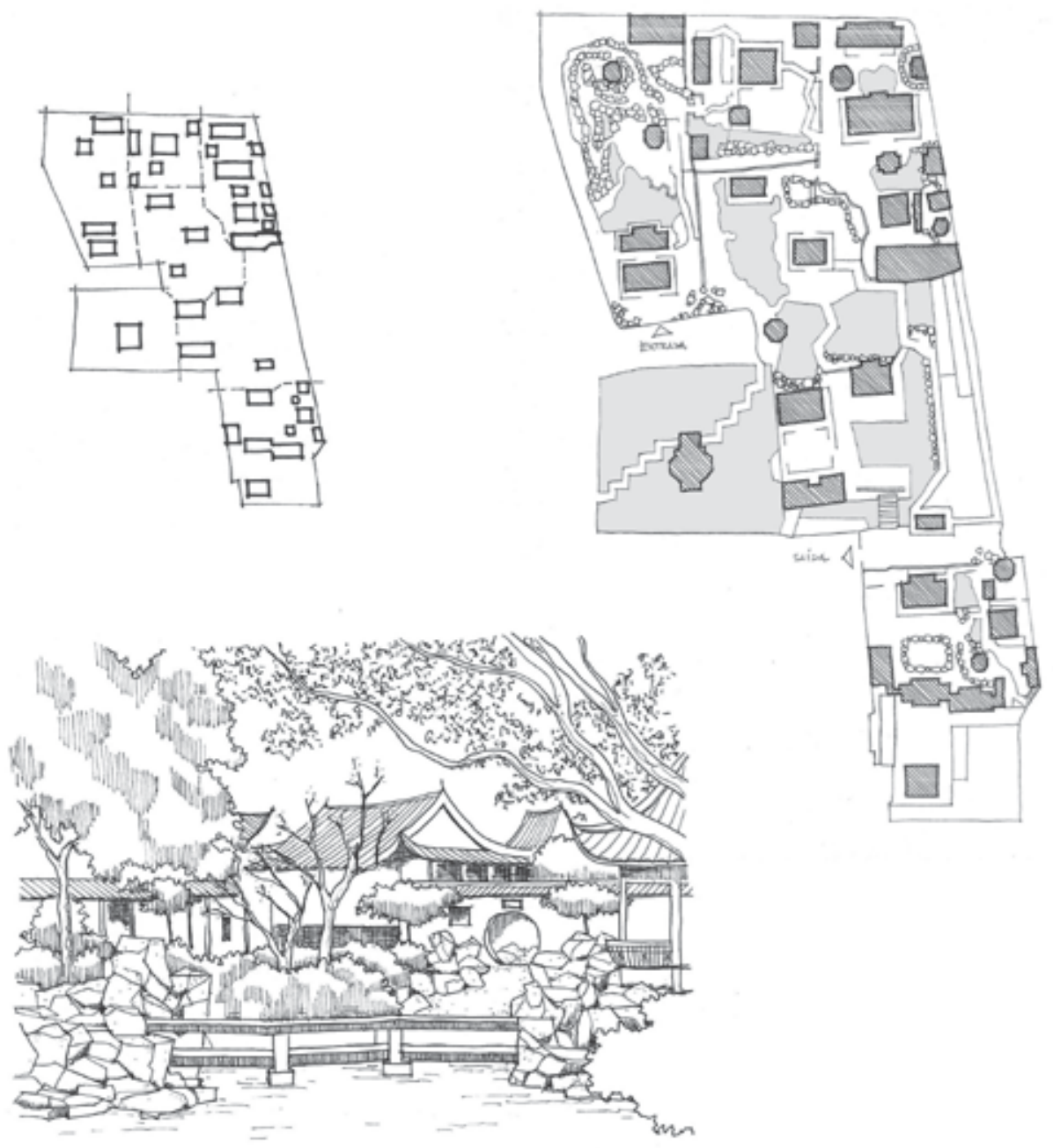

Figura 9 Representação do jardim Yuyuan em planta (acima, à direita), acompanhada por esquema indicativo da setorização do conjunto e da distribuição das edificações (acima, à esquerda). A perspectiva (abaixo, à esquerda) mostra um recanto próximo à entrada.

Autora: Cintia Maria Afonso, 2016.

Fonte: Panzini $(2013$, p. 389).

Também está presente no jardim o princípio taoista do yin e yang, representativo das forças complementares atuantes na natureza. Conjuntos de rochas que reproduzem montanhas chinesas estão presentes nos diversos setores do jardim, e as águas, representadas por pequenos lagos, permeiam os diversos ambientes e podem ser apreciadas em suas margens ou nos diversos caminhos que percorrem o jardim. Por vezes, esses caminhos atravessam os espelhos d'água para que o conjunto possa ser admirado em novos e inusitados ângulos.

Assim, no jardim chinês Yuyuan, o ideal taoista do homem que coexiste em harmonia com a natureza foi intencionalmente recriado a partir da arte oriental de construção de jardins. 


\subsection{A RECRIAÇÃO DA PAISAGEM NATURAL NO JARDIM ZEN JAPONÊS TENRYU-JI}

O jardim de Tenryu-ji foi intencionalmente criado para a contemplação, tendo sido um dos primeiros locais a expressar os ideais introduzidos pela prática zen budista.

A doutrina zen budista, originária da Índia, propunha a busca da paz espiritual sem rituais ou doutrinas elaboradas. Sendo assim, os jardins construídos nos mosteiros zen budistas estabeleceram uma estética sóbria e adquiriram caráter metafísico, ligado à prática da meditação. Seus templos incluíam áreas ajardinadas nas quais as paisagens naturais eram recriadas para fazer parte das atividades religiosas - não destinadas à prática de rituais, mas sim à contemplação.

O jardim de Tenryu-ji foi implantado em um mosteiro localizado em Kyoto, construído em 1339 em local anteriormente utilizado como residência aristocrática. A propriedade foi transformada em mosteiro zen quando o monge Muso Kokuchi, conhecido projetista de jardins, adaptou as condições preexistentes às necessidades da vida monástica (PANZINI, 2013, p. 414-415).

O desenho atual do setor do jardim que está em frente do pavilhão central ainda conserva características da intervenção feita por Kokuchi. O espaço é dominado por um lago de formato irregular, localizado na base de uma pequena colina. $\bigcirc$ conjunto abriga diversas composições de rochas na beira das águas, destacando-se um grupo de rochas extremamente verticais que foram posicionadas para simbolizar a iluminação e o sucesso. Esse grupo de rochas foi organizado de modo a formar uma cascata, que simboliza o esforço para atingir a iluminação (BOULTS; SULLIVAN, 2010, p. 52).

Os princípios adotados neste jardim foram difundidos pelo Japão e reelaborados nos inúmeros jardins aristocráticos construídos posteriormente - não mais voltados às atividades religiosas, mas relacionados à busca de contato harmonioso com o mundo natural.

\subsection{A ESSÊNCIA DA PAISAGEM NATURAL NO JARDIM KARESANSUI RYOAN-JI}

O jardim do mosteiro zen budista Ryoan-ji foi construído no século XV na região de Kyoto e é até hoje considerado um dos exemplos mais refinados de jardim karesansui, ou jardim seco, no qual a beleza efêmera das flores e plantas é substituída por elementos minerais, mais permanentes e resistentes ao tempo. Nesses jardins os elementos ancestrais do jardim japonês, como lagos e quedas d'água, são representados por materiais secos. As cascatas são representadas por arranjos de pedras e o movimento de ondulação das águas é representado por uma camada de cascalhos ou areia branca em cuja superfície é esculpido um padrão de sulcos.

Situado ao lado de um dos edifícios monásticos, o jardim seco de Ryoan-ji ocupa um espaço retangular, com aproximadamente o tamanho de uma quadra de tênis, delimitado por um muro baixo atrás do qual se ergue um grupo de árvores. Ali, quinze 
rochas, organizadas em cinco grupos, criam uma composição espacial dinâmica, na qual as forças visuais são balanceadas através de relações assimétricas, que podem ser percebidas em cada um dos grupos de pedras e em todo o conjunto (BOULTS; SULLIVAN, 2010, p. 620). Os grupos de pedras são rodeados por musgo, a única presença vegetal no jardim - possivelmente uma intervenção posterior. $\bigcirc$ restante do espaço é ocupado apenas por um fino pedrisco branco, trabalhado diariamente com o rastelo.
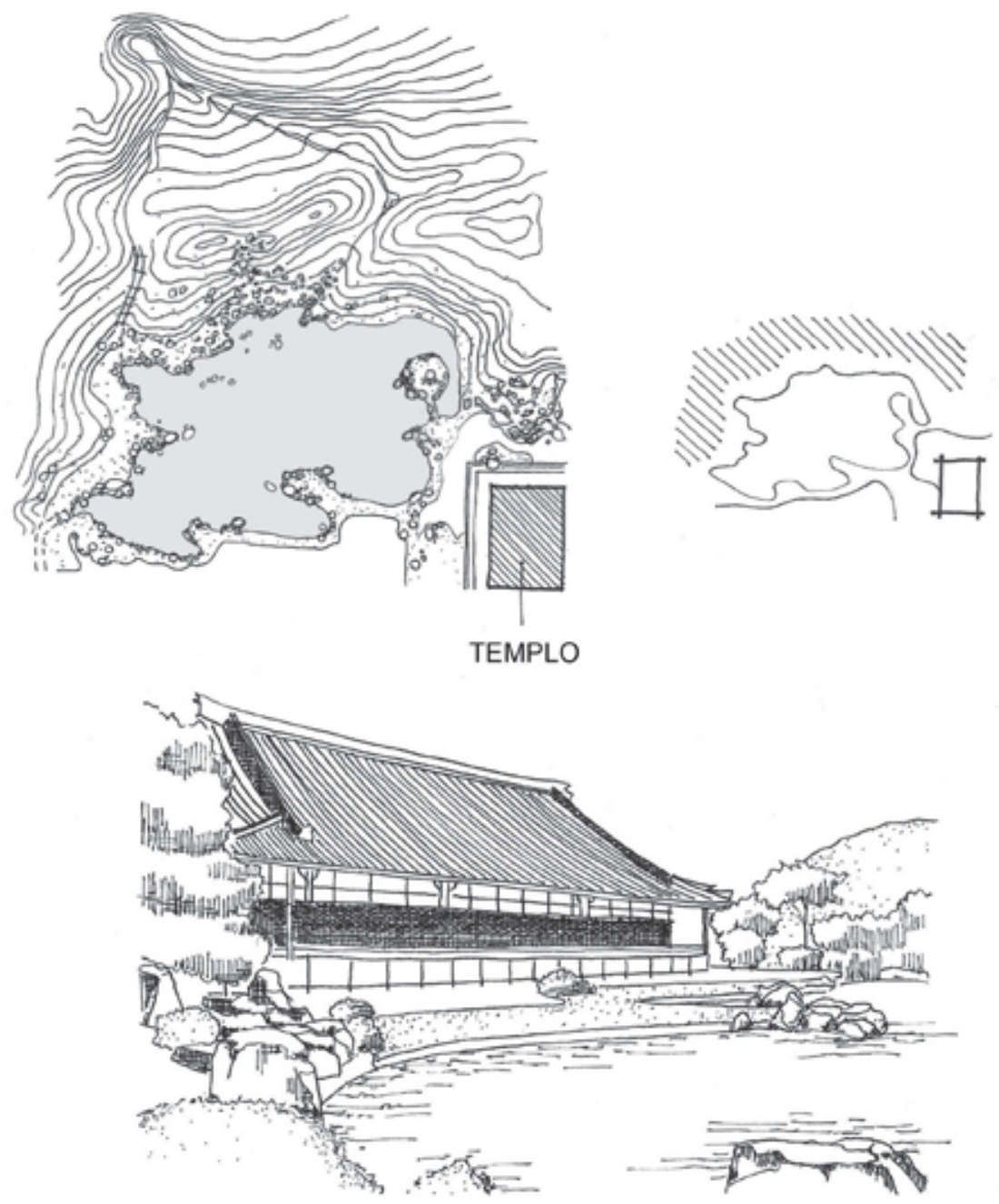

Figura 10 Representação do conjunto de Tenryu-ji em planta (acima, à esquerda), com indicações topográficas, traçado dos pequenos riachos que formam o lago central e posicionamento dos conjuntos de rochas. $O$ esquema (acima, à direita) indica a organização formal do conjunto, com lago e caminhos de formato irregular. A perspectiva (abaixo) mostra o templo e as composições de rochas à beira do lago.

Autora: Cintia Maria Afonso, 2016.

Fonte: Boults e Sullivan (2010, p. 51). 
Neste jardim, criam-se intencionalmente ilusões de distância e camadas espaciais similares às presentes nas pinturas chinesas. As visuais são enquadradas a partir de pontos de vista especialmente escolhidos e os arranjos verticalizados de rochas possivelmente evocam as montanhas sagradas chinesas. Criou-se, dessa forma, um conjunto de beleza disciplinada, trabalhado a fim de simular as características da paisagem natural em um ambiente adequado à contemplação.
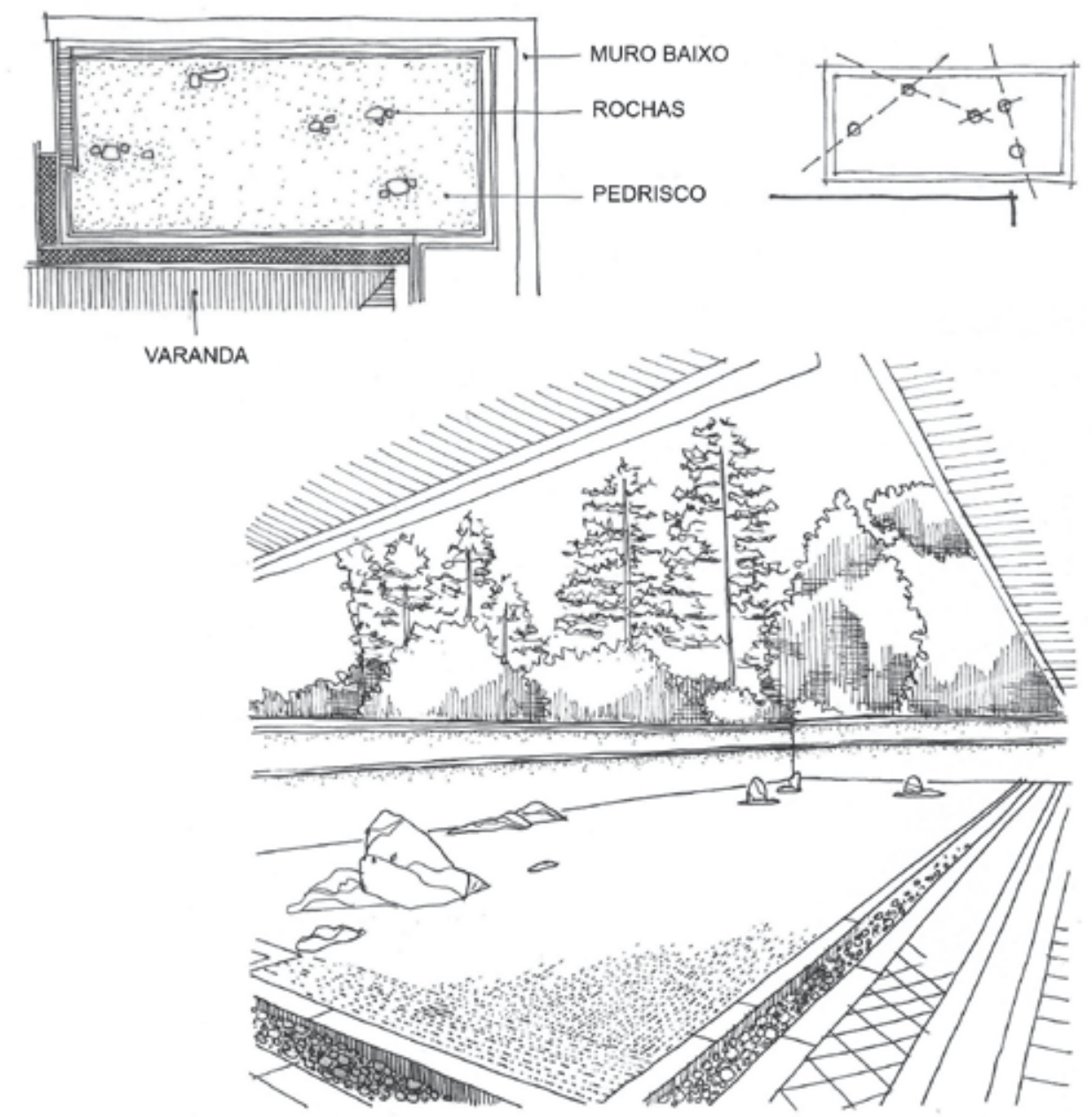

Figura 11 Representação em planta (acima, à esquerda) e perspectiva (abaixo) do jardim seco que faz parte do mosteiro Ryoan-ji. O esquema (acima, à direita) indica a organização formal dos conjuntos de rochas. Autora: Cintia Maria Afonso, 2016.

Fonte: Alex (1963, Plate 117).

O jardim Ryoan-ji foi construído para ser visto a partir da varanda do pavilhão monástico, e as pedras foram dispostas para que não fosse possível visualizar todas de uma só vez. Diz-se que somente os iluminados conseguem ver simultaneamente as quinze pedras. 
As interpretações a respeito deste jardim variam da matemática ao esoterismo. No entanto, é consenso que, após o impacto da primeira experiência visual, o observador começa a estabelecer relações entre os vários de seus elementos. O sentido da composição está na filosofia zen: existe uma qualidade cósmica - obtida mais através da contemplação do que da atividade (ALEX, 1963, p. 39-40). O verdadeiro significado do jardim Ryoan-ji está naquilo que o observador associa às vistas e nos significados que a elas atribui.

\section{JARDINS INGLESES DO SÉCULO XVIII A RUPTURA COM A REGULARIDADE}

Até o século XVIII, os jardins das grandes residências de campo inglesas eram formais e simétricos, seguindo o modelo francês. No entanto, nesse século, o estilo formal oriundo do continente europeu foi transformado - consequência do desejo crescente de distanciar a Inglaterra da ordem rígida indicativa do Absolutismo francês, que não agradava aos ingleses parlamentaristas (BOULTS; SULLIVAN, 2010, p. 151).

Desenvolveu-se, então, a proposta de criação de uma paisagem inglesa ideal, na qual se buscava recriar a paisagem natural através de uma relação harmoniosa entre esta e os elementos construídos. Esse conceito inovador foi intensamente influenciado pela poesia e pela pintura de paisagens, que promoveram mudanças nas teorias estéticas.

Poetas e escritores como Alexander Pope, Joseph Addison e Anthony Ashley Cooper denunciaram a tirania dos jardins estrangeiros e proclamaram a natureza como um ideal. Joseph Addison (1672-1719), escritor, jornalista e político, expressou em seus textos o prazer pelo campo bem cultivado. Alexander Pope (1688-1744), poeta, ensaísta e crítico, voltou sua ironia contra os jardins formais e divulgou a relação do novo estilo de jardim com a pintura de paisagens, estabelecendo analogias entre plantar e pintar. Em suas viagens ao exterior, os ingleses conheceram os campos italianos e adquiriram várias obras de arte que representavam estas paisagens, desenvolvendo o interesse pelas paisagens campestres, por um campo idealizado.

Também foram importantes as imagens e descrições dos jardins chineses trazidas à Europa pelos viajantes e missionários. Panzini (2013, p. 444-445) estabelece claramente a relação dos novos jardins ingleses com os jardins orientais:

[...] provavelmente, mais do que os historiadores tenham assumido até aqui, as informações sobre os jardins chineses enviadas à Europa a partir do século XVI pelos missionários jesuítas também contribuíram para essa conversão em direção a ambientes verdes entendidos como narrativas construídas por meio de uma sucessão de cenas. [...] Nos primeiros anos de missão, os jesuítas expressaram, juntamente com uma evidente fascinação, uma certa perplexidade diante de jardins que pareciam confusos e labirínticos e, em todo caso, muito diferentes dos europeus. Com o tempo, porém, eles mostraram compreender e apreciar sua estética baseada na surpresa, na assimetria, na manipulação das formas naturais e começaram até a recomendar esse estilo aos europeus, apontando nele uma pronunciada economia de meios e gestão, em contra- 
posição ao custo exorbitante dos grandes parques formais à francesa. Os intrigantes relatórios redigidos pelos jesuítas conheceram uma vasta difusão entre os estudiosos europeus já a partir do século XVII, e foi certamente após a leitura daquelas descrições que alguns autores ingleses começaram a se referir aos jardins orientais como uma possível fonte de inspiração para a nova modalidade compositiva que vinha nascendo.

A partir desses fatores, gradativamente se estabeleceram na Inglaterra novos parâmetros formais para a concepção dos jardins, agora compostos por colinas suaves, lagos de formas livres e conjuntos de árvores tratados de modo unificado. Também foi eliminada a típica separação entre o jardim e o restante da propriedade, agora configurada por uma cerca ou vala semienterrada, permitindo a integração visual entre $\circ$ jardim e a paisagem distante.

Iniciou-se, dessa forma, um novo tipo de relação com a paisagem natural, relação esta que transformou as propriedades agrícolas inglesas em lugares agradáveis e em consonância com o novo ideal de vida proposto para o país.

\subsection{AS FORMAS NATURAIS NO JARDIM INGLÊS DO SÉCULO XVIII - STOWE}

Uma das primeiras propriedades agrícolas a ser transformada em parque ao estilo inglês foi Stowe, localizada em Buckinghamshire. Suas terras foram adquiridas em 1589, por John Temple, e no século XVII passaram a ser propriedade de Richard Temple, influente político liberal (PANZINI, 2013, p. 446).

Até o final do século XVII, existiam ali uma velha fortaleza medieval e um pequeno jardim francês, mas ambos foram substituídos por um imponente palácio. As áreas externas foram inteiramente reformuladas, com a implantação de um jardim próximo à residência e a criação de um parque para caça e equitação nas áreas mais distantes. O parque foi separado do jardim por meio de um artifício inovador conhecido como ha-ha, que impedia a passagem dos animais, mas permitia que a paisagem fosse apreendida sem limites (JELLICOE, G.; JELLICOE, S., 1995, p. 233).

Ali trabalharam importantes paisagistas ingleses, como Charles Bridgeman, William Kent e Lancelot Brown. No processo de construção e modificação do conjunto, Stowe evoluiu gradativamente de um jardim simétrico para um jardim de formas naturais. A figura 12 mostra o resultado final desse processo de transformação, com o plantio de bosques ao longo dos limites do jardim interno, a implantação de dois lagos irregulares de aspecto natural, a construção de caminhos curvos e a formação de ambientes gramados emoldurados por vegetação, definindo limites suaves de subdivisão dos espaços.

Os jardins de Stowe evoluíram, assim, para uma configuração constituída por uma série de ambientes naturais apreciados ao caminhar, que substituíram a estratégia do ponto focal único e transformaram Stowe no mais famoso jardim inglês da primeira metade do século XVIII. 

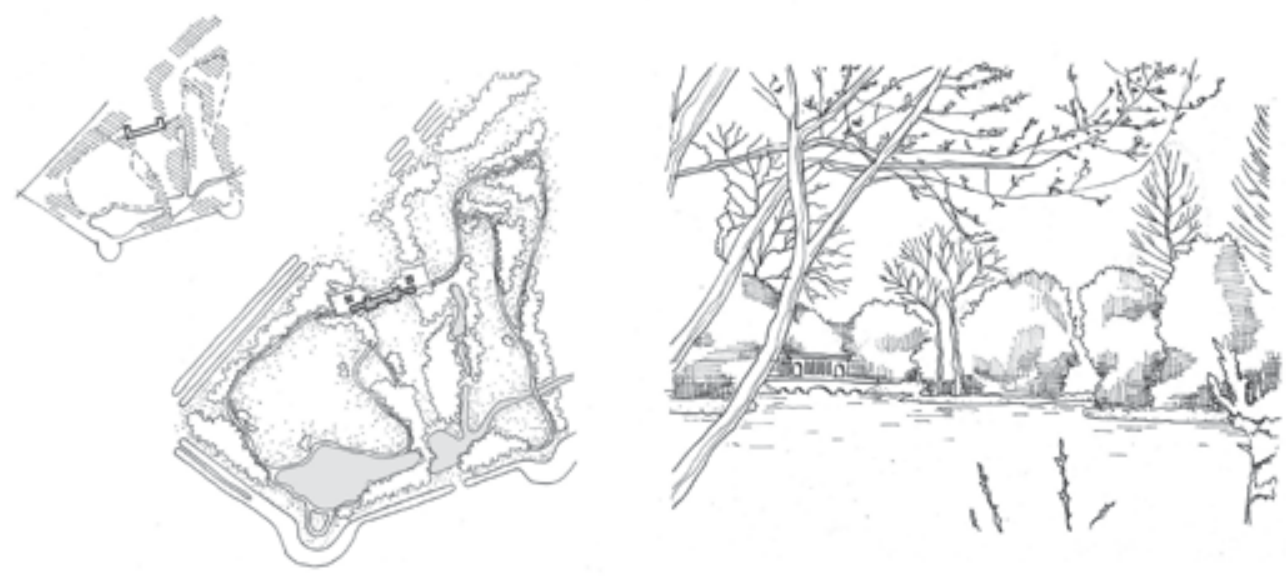

Figura 12 Implantação dos jardins internos de Stowe, com caminhos sinuosos, bosques e lagos de formato irregular (desenho central), acompanhada de esquema indicativo de sua organização formal (acima, à esquerda). A perspectiva (à direita) mostra um dos recantos do jardim.

Autora: Cintia Maria Afonso, 2016.

Fonte: Boults e Sullivan (2010, p. 158).

\section{CONCLUSÃO}

Os jardins da Antiguidade não permaneceram até nossos dias, mas pesquisas arqueológicas desenvolvidas no Egito e na Pérsia permitiram o estudo dos princípios compositivos neles adotados, indicando que eram baseados na regularidade e nos eixos de simetria.

Esse tipo de jardim foi adotado na Europa e na Índia. No entanto, o Taj Mahal, construído na Índia a partir de princípios tipicamente persas, é considerado por estudiosos como um jardim construído por povos invasores a partir de tradições externas ao país.

Os jardins chineses e japoneses analisados mostraram a adoção de princípios de projeto baseados na compartimentação de espaços, na assimetria e na complementaridade de formas. Esse tipo de jardim foi difundido na Europa através dos relatos de viajantes e missionários que viveram no Oriente, tendo sido retrabalhado pelos ingleses durante o século XVIII, período em que se fortaleceu o desejo de distanciar a Inglaterra parlamentarista dos regimes autoritários da Europa continental. $\bigcirc$ jardim inglês analisado foi construído nesse período, adotando formas irregulares, lagos, caminhos curvos e ambientes gramados emoldurados por bosques de aspecto natural. 


\section{REFERÊNCIAS BIBLIOGRÁFICAS}

ALEX, William. Japanese architecture. London: Prentice Hall, 1963.

ARAGÃO, S. de. Ensaio sobre o jardim. São Paulo: Global, 2008.

BARRAL I ALTET, Xavier. O mundo românico: cidades e mosteiros. Colonia: Taschen, 2001.

BERRALL, Julia S. The garden: an illustrated history. New York: Penguin, 1978.

BOULTS, E.; SULLIVAN, C. Illustrated history of landscape design. New Jersey: John Wiley, 2010.

COLE, Emily (Org.). História ilustrada da arquitetura. São Paulo: Publifolha, 2014.

HOAG, John D. Western islamic architecture. London: Prentice Hall, 1963.

JELLICOE, G.; JELLICOE, S. The landscape of man: shaping the environment from prehistory to the present day. 3 ed. New York: Thames \& Hudson, 1995.

KIDD, Fiona. Ideas of empire: the "royal garden" at Pasargadae. 29 jul. 2013. Disponível em: $<$ http://www.metmuseum.org/about-the-museum/now-at-the-met/features/2013/pasargadae > . Acesso em: 23 jul. 2015.

LAURIE, M. Introducción a la arquitectura del paisaje. Barcelona: Gustavo Gili, 1983.

LODARI, Carola. II giardino giapponese: storia, arte e simbolismo. In: CONTI, A. (Org.). Giardini: I'arte del verde attraverso i secoli. Firenze: Giunti, 2005, p. 152-173.

MACEDO, Silvio Soares. Quadro do paisagismo no Brasil. São Paulo: Edusp, 1999.

PARKER, Geoffrey (Ed.). Atlas da história do mundo. 4 ed. São Paulo: Times, 1995.

SANTOS, Milton. Metamorfoses do espaço habitado. 3 ed. São Paulo: Hucitec, 1994.

STRONACH, David. Pasargadae: a report on excavations conducted by the British Institute of Persian Studies from 1961 to 1963. Oxford: Clarendon, 1978. 